\title{
Dampak Kejelasan Sasaran Anggaran dan Komitmen Organisasi dalam Meningkatkan Kinerja Aparat Pemerintah Daerah Kota Pematangsiantar
}

\section{Lenny Dermawan Sembiring}

Sekolah Tinggi Ilmu Ekonomi Sultan Agung

lennydermawansembiring@stiesultanagung.ac.id

\section{Acai Sudirman}

Sekolah Tinggi Ilmu Ekonomi Sultan Agung

acaivenly@stiesultanagung.ac.id

\section{Hery Pandapotan Silitonga}

Sekolah Tinggi Ilmu Ekonomi Sultan Agung

hery@stiesultanagung.ac.id

\begin{abstract}
Abstrak The purpose of this research was (1) to test and analyze the influence of the clarity of the budget targets on the performance of local government. (2) to test and analyze the influence of organization commitment on the performance of local government. (3) to test and analyze the influence clarity of the budget targets and organization commitment on the performance of local government. Data were obtained from local government Kota Pematangsiantar. The sample used in this study were 46 local government Kota Pematangsiantar, with respondents of 46 head of department in local government Kota Pematangsiantar. The datawere gathered using questionnaire and methods used in this research were multiple linear regression analysis. The results showed that (1) clarity of the budget targets has influence on performance of local government Kota Pematangsiantar. (2) organization commitment has influence on performance of local government Kota Pematangsiantar. (3) clarity of the budget targets and organization commitment has influence on performance local government Kota Pematangsiantar.
\end{abstract}

Kata Kunci Clarity of the Budget Targets, Organization Commitment, performance local government

\section{PENDAHULUAN}

Organisasi harus melakukan adaptasi secara efektif dan terus-menerus terhadap perubahan konstan jika ingin meraih kesuksesan yang lebih tinggi pada tingkat perubahan yang dalam (Sahir, et al., 2020). Dalam mengelola keuangan pemerintahan daerah yang kredibel dibutuhkan reaksi yang cepat dari kinerja aparat pemerintah daerah (Silitonga, Widia dan Irfan, 2018). Interpretasi yang berbasis prestasi untuk aparat dalam mengelola pos-pos anggaran sudah dirumuskan dalam PP No.105/2000 tentang pengelolaan dan pertanggungjawaban keuangan daerah termasuk hak dan kewajiban dalam melaksanakan penyelenggaraan pemerintahan daerah yang dapat diukur dengan uang termasuk segala 


\section{JESYA}

JURNAL EKONOMI \& EKONOMI SYARIAH

Jurnal Ekonomi \& Ekonomi Syariah Vol 3 No 2, Juni 2020

E-ISSN : 2599-3410|P-ISSN : 2614-3259

DOI : https://doi.org/10.36778/jesya.v3i2.225

bentuk kekayaan yang berhubungan dengan hak dan kewajiban. Implementasi dan konsolidasi keuangan pemerintah daerah sebenarnya telah diatur dalam Undang-undang Nomor 32 Tahun 2004 tentang Pemerintah Daerah, memberikan perubahan penting untuk pengelolaan Anggaran Daerah. Berdasarkan PP Nomor 58 Tahun 2005 menjelaskan bahwa sistem anggaran sebaiknya berorientasi pada pencapaian hasil kerja dan keluaran biaya berdasarkan porsi dan susunan rencana yang telah ditetapkan sehingga realisasi anggaran dapat terlaksana secara maksimal.

Anggaran memiliki pengaruh yang esensial terhadap lingkungan pemerintahan karena implikasinya terhadap akuntabilitas pemerintahan berhubungan dengan fungsi pemerintah dalam memberikan pelayanan kepada masyarakat (Suleman et al., 2020).Sumber daya dan input memiliki peranan penting dalam mempersiapkan pengendaliananggaranagar perkiraan biaya terdistribusi kepada individu atau departemen (Jalaluddin dan Dafi, 2009). Penyusunan kejelasan sasaran anggaran berkaitan dengan pada individu yakni aparat dalam menyusun perkiraan biaya sesuai dengan sasaran instansi/dinas/SKPD, sehingga mempermudah untuk memformulasikan capaian anggaran kedepannya (Manurung, Nasrullah dan Emilia, 2019). Kejelasan sasaran anggaran dalam konteks pemerintah daerah memiliki implikasi pada aparatur dalam merencanakan serta merumuskan anggaran berdasarkan sasaran yang akan dicapai oleh pemerintah, sehingga untuk kedepannya setiap aparatur memiliki cukup waktu dan informasi dalam memprediksi anggaran yang harus ditetapkan.

Manifestasi peningkatan dan penurunan kinerja tergantung pada sejauh mana individu lebih mementingkan diri sendiri dalam bekerja atau bekerja sama demi kepentingan organisasinya (Siwi, Alwan dan Novi, 2018). Sikap untuk memperlihatkan kepercayaan dan dukungan yang kuat terhadap target kuantitas yang akan diraih oleh organisasi. Komitmen organisasi yang tinggi akan berdampak pada paradigma positif individu dalam bekerja untuk mencapai tujuan organisasi yang telah ditetapkan (Suryana, Edy and Putu, 2017). Representatif komitmen yang kuat bersumber dari komitmen organisasi yang ditingkatkan secara terus menerus sehingga membantu organisasi dalam mencapai tujuan yang telah ditetapkan. Semakin tinggi komitmen yang dimiliki seorang pegawai maka akan berimplikasi pada peningkatan kinerja serta memberikan citra yang baik untuk instansi tempat pegawai tersebut bekerja (Harahap and Abdullah, 2016).

Penelitian mengenai pengaruh kejelasan sasaran anggaran terhadap kinerja aparatur pemerintah daerah sudah pernah dilakukan oleh (Nurhalimah, Darwanis and Syukriy, 2013) dan (Mulyadi, Syamsidar and Dedy, 2018) yang menyatakan bukti empiris hasil penelitian menyebutkan tidak terdapat pengaruh dari kejelasan sasaran anggaran terhadap kinerja aparatur perangkat daerah. Sedangkan pada hasil penelitian (Mulyadi, Syamsidar and Dedy, 2018) dan (Nugroho and Sumiyanti, 2017) menyatakan terdapat pengaruh positif dan signifikan antara kejelasan sasaran anggaran terhadap kinerja aparatur pemerintah. Selanjutnya pada penelitian (Widhi and Erma, 2015) dan (Qotrunnada, Wiratno and Supeno, 2018) menyebutkan bahwa komitmen organisasi tidak berpengaruh signifikan terhadap kinerja. Sedangkan pada hasil penelitian (Amanta, Putra and Werastuti, 2015), mengemukakan bahwa terdapat pengaruh positif dan signifikan antara komitmen organisasi terhadap kinerja.

Berdasarkan uraian di atas, maka peneliti berkesimpulan adanya gap antara hasil penelitian sebelumnya dengan teori yang ada sehingga peneliti berniat mengambil judul penelitian "Peran Kejelasan Sasaran Anggaran dan Komitmen Organisasi Dalam Meningkatkan Kinerja Aparat Pemerintah Daerah Kota Pematangsiantar". 


\section{LANDASAN TEORI}

\subsection{Kejelasan Sasaran Anggaran}

Berdasarkan Permendagri No. 13/2006 dan diperbaharui dengan Permendagri No. 59/2007 tentang panduan untuk daerah mengelola keuangannya, disebutkan tentang penyusunan Rencana Kerja dan Anggaran Satuan Kerja Perangkat Daerah (RKA-SKPD) untuk memenuhi kebutuhan perhitungan biaya sesuai dengan prestasi dan akuntabilitas, diperlukan hasil yang optimal, efisien dan efektif dengan kejelasan sasaran anggaran. Penyusunan anggaran yang kontradiksi dengan kinerja berimplikasi terhadap kegagalan perencanaan yang telah disusun. Menurut (Bastian, 2006), pengukuran kinerja secara continueakan memberikan umpan balik, sehingga keberhasilan di masa yang akan datang dapat dicapai apabila dilakukan perbaikan secara terus menerus. Perkiraan biaya yang telah disusun dan ditetapkan bukan hanya sebagai tujuan biaya dan pendapatan bagi pusat-pusat tanggungjawab, melainkan juga sebagai sarana untuk kontrol, komunikasi, koordinasi, evaluasi kinerja dan motivasi (Abdullah, Wa Ode dan Astrinigita, 2017).

\subsection{Komitmen Organisasi}

Variabel lain yang dianggap berpengaruh pada peningkatan kinerja aparat pemerintah daerah yaitu komitmen organisasi.Menurut pendapat (Weiner, 2004), komitmen organisasi merupakan inisiatif yang muncul dari dalam pribadi seseorang untuk melakukan sesuatu hal sehingga dapat mendukung kesuksesan organisasi sesuai dengan tujuan yang ditetapkan dan memprioritaskan kepentingan organisasi ketimbang kepentingan sendiri. Komitmen organisasi dijadikan sebagai tolak ukur untuk melihat kredibilitas aparat pemerintah daerah memihak suatu organisasi tertentu serta untuk mempertahankan keanggotaannya dalam suatu organisasi. Menurut (Griffin, 2002), komitmen organisasi merupakan perilaku yang merepresentasikan kredibilitas seorang individu terikat dan mengenal organisasinya.

\subsection{Kinerja}

Pemerintah dalam arti luas merujuk kepada aparatur negara sebagai alat-alat kelengkapan yang merupakan kesatuan dalam proses administrasi penyelenggaraan pemerintah (Silalahi et al., 2020). Untuk meningkatkan efisiensi pendistribusian sumber daya dan efektivitas penggunaannya sesuai dengan susunan rencana yang telah ditetapkan sebaiknya berorientasi pada penerapan anggaran (Aziz, Akmal \& Anwar, 2016). Relevansi untuk mengukur kinerja khususnya pendekatan kinerja memiliki beberapa kelemahan yang disebabkan oleh tidak adanya instrument yang bisa digunakan untuk menilai prestasi dalam pencapaian tujuan dan tumpuan pelayanan umum berorientasi pada pendekatan anggaran berbasis kinerja (Mardiasmo, 2006). Representatif realisasi anggaran dikelola berdasarkan prestasi kerja/anggaran kinerja sehingga memberikan sinyal tentang perubahan yang mendasar terhadap agenda dan perkiraan dana di daerah. Manifestasi pelaksanaan program kerja dan kegiatan yang berorientasi pada penggunaan APBD sebaiknya diformulasikan secara jelas dan dapat terukur output dan outcomenya.

\subsection{Kejelasan Sasaran Anggaran Terhadap Kinerja Aparat Pemerintah Daerah}

Menurut (Halim and Syam Kusun, 2012) mengatakan bahwa anggaran memiliki peranan penting dalam organisasi sektor publik, terutama organisasi pemerintahan. Anggaran yang baik tidak hanya memuat informasi tentang pendapatan, belanja dan pembiayaan namun lebih dari itu anggaran merupakan pernyataan mengenai estimasi kinerja yang hendak dicapai selama periode waktu tertentu yang dinyatakan dalam ukuran 
finansial (Mardiasmo, 2009, hal 61). Berdasarkan pendapat Locke dan Lathan (1990), ada 7 indikator yang diperlukan untuk mengukur kejelasan sasaran anggaran yaitu tujuan, kinerja, standar, jangka waktu, sasaran prioritas, tingkat kesulitan dan koordinasi. Berdasarkan hasil penelitian Kewo dan Nunuy (2017) serta Abdullah, Wa Ode dan Astrinigita (2017), menyatakan bahwa kejelasan sasaran anggaran berpengaruh positif terhadap kinerja. Adanya realisasi target anggaran yang baik serta memiliki tendensi kesesuaian dengan Rencana Kerja Anggaran (RAK) akan mempengaruhi pertanggungjawaban kinerja Aparat Pemerintah Daerah. Selanjutnya temuan yang sama juga dibuktikan dengan hasil temuan (Manurung, Dali and Nurdin, 2019) dan (Jalaluddin and Dafi, 2009), (Anwar, 2018), (Hidayat, 2016), serta (Nengsy, 2017) yang menyatakan bahwa kejelasan anggaran memiliki pengaruh yang positif terhadap kinerja Instansi dan Aparat Pemerintah Daerah. Hasil ini membuktikan bahwa kejelasan anggaran yang disusun dengan objektif dan terimplementasi dengan optimal dapat meningkatkan kinerja aparat pemerintah daerah.

\section{$H_{1}$ : Kejelasan sasaran anggaran berpengaruh positif terhadap kinerja aparat pemerintah daerah.}

\subsection{Komitmen Organisasi Terhadap Kinerja Aparat Pemerintah Daerah}

Menurut Robbins dan Judge (2013, hal 343) mengungkapkan bahwa komitmen organisasi yaitu "Organizational commitment is the degree to which an employeeidentifies with a particular organization and its goals and wishes to maintain membership in the organization". Komitmen organisasi adalah sejauh mana seorang karyawan mengidentifikasi suatu organisasi untuk dapat mencapai tujuannya serta seberapa besar keinginan karyawan untuk tetap mempertahankan keanggotaan dalam organisasi. Pendapat tentang komitmen organisasi dikemukakan oleh (Aan and Cepi, 2005) pengertian komitmen organisasi adalah suatu keadaan di mana seorang karyawan memihak pada suatu organisasi tertentu beserta tujuannya dan berniat memelihara keanggotaan dalam organisasi itu. Untuk mengukur komitmen organisasi dibutuhkan indikator seperti yang dikemukakan oleh (Allen and Meyer, 1997), yaitu komitmen afektif, komitmen kontinu dan komitmen normatif. Sesuai hasil penelitian (Siwi, Kustomo and Puspitasari, 2018) dan (Suryana, Edy and Putu, 2017), menyatakan bahwa komitmen organisasi berpengaruh positif terhadap kinerja aparatur pemerintah. Komitmen menunjukkan keyakinan dukungan yang kuat terhadap sasaran yang akan dicapai organisasi. Semakin tinggi komitmen dalam berorganisasi maka akan semakin menumbuhkan motivasi dalam bekerja yang berimplikasi terhadap kinerja itu sendiri. Kemudian temuan selanjutnya dibuktikan dengan penelitian oleh Harahap and Abdullah (2016), yang menemukan bahwa komitmen organisasi berpengaruh positif terhadap kinerja aparatur pemerintahan. Komitmen yang tinggi berdampak terhadap aktualisasi diri yang baik dalam bekerja seperti munculnya hati yang senang dan perilaku semangat kerja dalam melakukan aktivitas pekerjaan.

\section{$H_{2}$ : Komitmen organisasi berpengaruh positif terhadap kinerja aparat pemerintah daerah.}

Berdasarkan uraian dan pengembangan hipotesis di atas, dihasilkan kerangka pemikiran teoritis sebagai berikut: 


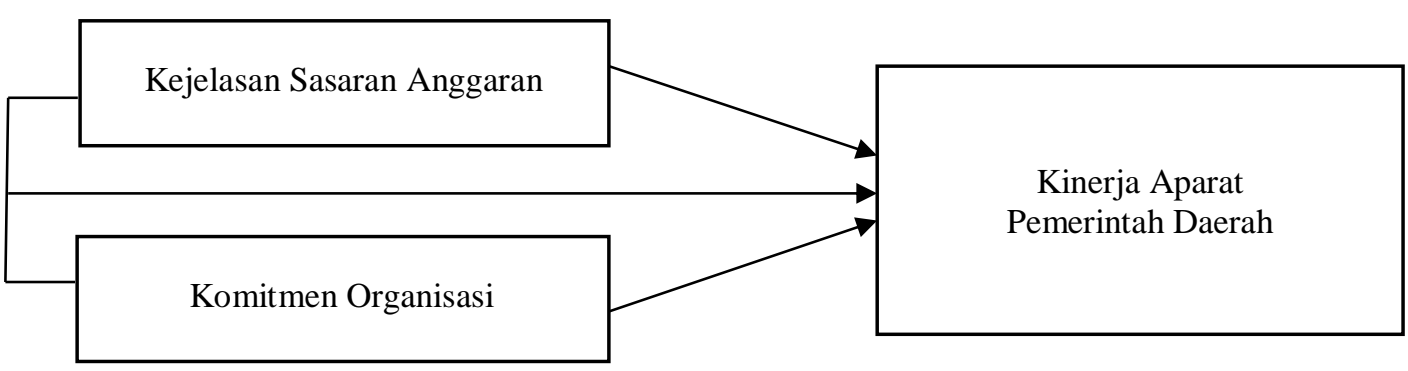

Gambar 1. Kerangka Pemikiran

\section{METODOLOGI PENELITIAN}

Populasi dalam penelitian ini adalah aparat pemerintah daerah Kota Pematangsiantar. Sampel pada penelitian ini menggunakan sampel jenuh, yaitu keseluruhan populasi digunakan sebagai sampel. Sampel pada penelitian ini berjumlah 46 Pemerintah Daerah Kota Pematangsiatar dengan respondennya 46 kepala/pimpinan Pemerintah Daerah Kota Pematangsiantar.Data yang digunakan dalam penelitian ini adalah data primer. Pengumpulan data primer diperoleh dengan survei ke lapangan menggunakan kuesioner. Analisis data dalam penelitian ini menggunakan analisis regresi linier berganda dan pengujian hipotesis yang sebelumnya telah diuji kualitas datanya melalui uji validitas dan reliabilitas. Kemudian setelah uji validitas dan reabilitas memenuhi syarat, selanjutnya dilakukan uji asumsi klasik yang terdiri dari uji normalitas, uji heteroskedastisitas, dan uji multikolinieritas.

\section{HASIL PENELITIAN}

\subsection{Uji Kualitas Data}

Untuk mengukur validitas data kuesioner, dilakukan dengan cara mengkorelasikan skor item butir-butir pertanyaan terhadap skor totalnya. Data dikatakan valid apabila nilai rhitung atau corrected item total correlation lebih besar dari nilai rtabel sebesar 0,3. Nilai validitas untuk kejelasan sasaran anggaran diperoleh nilai rata-rata sebesar 0,58, kemudian untuk komitmen organisasi diperoleh nilai rata-rata sebesar 0,63 , selanjutnya untuk kinerja aparat pemerintah diperoleh nilai rata-rata sebesar 0,64, maka dapat disimpulkan semua item pertanyaan adalah valid. Dari uji reabilitas diperoleh hasil nilai cronbach's alpha if item deleted dengan nilai $>0,70$. Hal tersebut mengindikasikan bahwa semua item pertanyaan adalah reliabel.

\subsection{Uji Asumsi Klasik}

Dari hasil Kolmogorov-Smirnov test diperoleh Asymp.Sig (2-tailed) untuk kejelasan sasaran anggaran diperoleh nilai sebesar 0,611 , untuk komitmen organisasi diperoleh nilai 0,328 dan kinerja aparat pemerintah diperoleh nilai 0,677lebih besar daripada 0,05, sehingga dapat disimpulkan bahwa semua variabel data berdistribusi normal. Dari hasil uji heteroskedastisitas diperoleh kesimpulan tidak terjadi gejala heteroskedastisitas. Selanjutnya untuk hasil multikolinieritas diperoleh nilai tolerance 0,998 > 0,1 dan VIF $1,002<10$, sehingga dapat disimpulkan bahwa tidak terjadi multikolinieritas. 


\subsection{Pengujian Hipotesis}

\subsubsection{Analisis Regresi Linier Berganda}

Setelah semua data telah melewati proses pengujian kualitas data dan uji asumsi klasik, maka tahap selanjutnya adalah mencari nilai pengaruh variabel indenpenden terhadap variabel dependen, yakni pengaruh kejelasan sasaran anggaran dan komitmen organisasi terhadap kinerja aparat pemerintah daerah. Hasil pengujian regresi dapat dilihat pada tabel berikut ini:

Tabel 1. Hasil Regresi Linier Berganda

\begin{tabular}{|c|c|c|c|}
\hline \multirow[t]{2}{*}{ Model } & \multicolumn{2}{|c|}{$\begin{array}{c}\text { Unstandardized } \\
\text { Coefficients }\end{array}$} & $\begin{array}{l}\text { Standardized } \\
\text { Coefficients }\end{array}$ \\
\hline & $\mathrm{B}$ & Std. Error & Beta \\
\hline (Constant) & 4,390 & 6,094 & \\
\hline 1 Kejelasan.Sasaran.Anggaran & ,466 & ,092 & ,495 \\
\hline Komitmen.Organisasi &, 842 & 146 &, 565 \\
\hline
\end{tabular}

Dependent Variable: Kinerja Aparat Pemerintah Daerah

Sumber: Data diolah tahun 2019

$\mathrm{Y}=\alpha+\beta_{1} \mathrm{X}_{1}-\beta_{2} \mathrm{X}_{2}+\mathrm{e}$

Kinerja Aparat Pemerintah Daerah $=4,390+0,466$ Kejelasan Sasaran Anggaran +0,842

Komitmen Organisasi.

Keterangan dari persamaan linier tersebut adalah sebagai berikut:

1) Konstanta sebesar 4,390 dengan arah hubungannya positif menunjukkan bahwa apabila variabel kejelasan sasaran anggaran dan komitmen organisasi dianggap konstan maka kinerja aparat pemerintah daerah telah terbentuk sebesar 4,390.

2) Koefisien regresi pengaruh kejelasan sasaran anggaran terhadap kinerja aparat pemerintah daerah adalah positif sebesar $\mathbf{0 , 4 6 6}$, artinya apabila kejelasan sasaran anggaran ditingkatkan satu satuan maka akan meningkatan kinerja aparat pemerintah daerah sebesar $\mathbf{0 , 4 6 6}$.

3) Koefisien regresi pengaruh komitmen organisasi terhadap kinerja aparat pemerintah daerah adalah positif sebesar $\mathbf{0 , 8 4 2}$, yang artinya apabila komitmen organisasi ditingkatkan satu satuan maka akan meningkatan kinerja aparat pemerintah daerah sebesar $\mathbf{0 , 8 4 2}$.

\subsubsection{Uji Model Simultan (Uji F)}

Berdasarkan hasil analisis pada tabel dibawah ini diperoleh nilai F sebesar 30,697 dan tingkat signifikansi sebesar 0,000. Hasil nilai signifikansi jauh lebih kecil dari 0,05, yang artinya salah satu dari dua variabel indenpenden yaitu kejelasan sasaran anggaran dan komitmen organisasi berpengaruh terhadap kinerja aparat pemerintah daerah.

Tabel 2. Hasil Uji Model Simultan (Uji F)

\begin{tabular}{|l|r|r|r|r|l|}
\hline \multicolumn{1}{|c|}{ Model } & \multicolumn{1}{|c|}{ Sum of Squares } & Df & Mean Square & F & Sig. \\
\hline Regression & 818,848 & 2 & 409,424 & $\mathbf{3 0 , 6 9 7}$ & $\mathbf{, 0 0 0}^{\mathbf{b}}$ \\
Residual & 573,522 & 43 & 13,338 & & \\
Total & 1392,370 & 45 & & & \\
\hline
\end{tabular}

a. Dependent Variable: Kinerja.Aparat.Pemerintah.Daerah

b. Predictors: (Constant): Komitmen.Organisasi, Kejelasan.Sasaran.Anggaran Sumber: Data diolah tahun 2019 


\subsubsection{Uji Model Parsial (Uji Statistik t)}

Uji t adalah uji yang dilakukan untuk mengetahui apakah antara variabel bebas yaitu kejelasan sasaran anggaran dan komitmen organisasi dan variabel terikat yaitu kinerja aparat pemerintah mempunyai hubungan yang signifikan atau tidak. Berikut ini disajikan hasil pengujian statistik dengan uji t:

Tabel 4. Hasil Uji Statistik t

\begin{tabular}{|c|c|c|c|c|}
\hline \multirow[t]{2}{*}{ Model } & \multicolumn{2}{|c|}{ Unstandardized Coefficients } & \multirow[t]{2}{*}{$\mathrm{t}$} & \multirow[t]{2}{*}{ Sig. } \\
\hline & $\mathrm{B}$ & Std. Error & & \\
\hline (Constant) & 4,390 & 6,094 &, 720 & 475 \\
\hline Kejelasan.Sasaran.Anggaran & ,466 & ,092 & 5,056 & ,000 \\
\hline Komitmen.Organisasi & ,842 & , 146 & 5,764 & ,000 \\
\hline
\end{tabular}

Dependent Variable: Kinerja Aparat Pemerintah Daerah

Sumber: Data diolah tahun 2019

1. Kejelasan sasaran anggaran berpengaruh terhadap kinerja aparat pemerintah daerah. Variabel kejelasan sasaran anggaran memiliki nilai t sebesar 5,056 dan tingkat signifikansi sebesar 0,000. Hal ini menunjukkan bahwa $0,000<0,05$, maka $\mathrm{H}_{1}$ dapat didukung dan disimpulkan bahwa kejelasan sasaran anggaran berpengaruh terhadap kinerja aparat pemerintah daerah.

2. Komitmen organisasi berpengaruh terhadap kinerja aparat pemerintah daerah. Variabel komitmen organisasi memiliki nilai t sebesar 5,056 dan tingkat signifikansi sebesar 0,000 . Hal ini menunjukkan bahwa $0,000<0,05$, maka $\mathrm{H}_{2}$ dapat didukung dan disimpulkan bahwa komitmen organisasi berpengaruh terhadap kinerja aparat pemerintah daerah.

\subsubsection{Koefisien Determinasi}

Koefisien determinasi ini berfungsi untuk mengetahui persentase besarnya pengaruh variabel independen dan variabel dependen yaitu dengan mengkuadratkan koefisien yang ditemukan. Koefisien ini disebut koefisien penentu, karena varians yang terjadi pada variabel dependen dapat dijelaskan melalui varians yang terjadi pada variabel independen. Berikut ini disajikan hasil uji koefisien determinasi:

Tabel 5. Hasil Uji Koefisien Determinasi

\begin{tabular}{|l|c|r|r|r|}
\hline Model & $\mathrm{R}$ & R Square & Adjusted R Square & Std. Error of the Estimate \\
\hline 1 &, $767^{\mathrm{a}}$ &, 588 & $\mathbf{5 6 9}$ & 3,652 \\
\hline
\end{tabular}

a. Predictors: (Constant): Komitmen Organisasi, Kejelasan Sasaran Anggaran

b. Dependent Variable: Kinerja Aparat Pemerintah Daerah

Sumber: Data diolah tahun 2019

Berdasarkan hasil output SPSS di atas menunjukkan besarnya nilai adjusted $R$ square sebesar 0,569 yang artinya kinerja aparat pemerintah daerah dipengaruhi 56,9\% oleh kejelasan sasaran anggaran dan komitmen organisasi, sedangkan sisanya oleh faktor lain diluar variabel penelitian. 


\subsection{Pengaruh Kejelasan Sasaran Anggaran terhadap Kinerja Aparat Pemerintah Daerah}

Hipotesis pertama pada penelitian ini adalah kejelasan sasaran anggaran berpengaruh positif terhadap kinerja aparat pemerintah daerah. Berdasarkan nilai thitung sebesar 5,056 > 2,015 dan nilai signifikansi 0,000 $<0,05$, maka $\mathrm{H} 0$ ditolak dan $\mathrm{H}_{1}$ diterima. Kesimpulannya adalah kejelasan sasaran anggaran berpengaruh secara signifikan terhadap kinerja aparat pemerintah daerah. Hasil penelitian ini sejalan dengan penelitian yang dilakukan oleh (Mulyadi and Syamsidar, 2017), dan (Manurung, Nasrullah and Emilia, 2019) bahwa kejelasan sasaran anggaran berpengaruh positif dan signifikan terhadap kinerja aparat pemerintah.

\subsection{Pengaruh Komitmen Organisasi terhadap Kinerja Aparat Pemerintah Daerah}

Hipotesis pertama pada penelitian ini adalah komitmen organisasi berpengaruh positif terhadap kinerja aparat pemerintah daerah. Berdasarkan nilai thitung sebesar 5,764 $>$ 2,015 dan nilai signifikansi $0,000<0,05$, maka $\mathrm{H} 0$ ditolak dan $\mathrm{H}_{2}$ diterima. Kesimpulannya adalah komitmen organisasi berpengaruh secara signifikan terhadap kinerja aparat pemerintah daerah. Hasil penelitian ini sejalan dengan hasil penelitian yang dilakukan oleh (Siwi, Alwan and Novi, 2018), (Suryana, Edy and Putu, 2017) serta (Harahap and Abdullah, 2016), bahwa komitmen organisasi berpengaruh positif dan signifikan terhadap kinerja aparat pemerintah.

\section{KESIMPULAN}

Berdasarkan data yang telah dikumpulkan dan diuji, maka dapat disimpulkan bahwa dampak Kejelasan Sasaran Anggaran dan Komitmen Organisasi berpengaruh positif secara signifikan terhadap peningkatan Kinerja Aparat Pemerintah Daerah Kota Pematangsiantar. Hal ini mengindikasikan bahwa dengan adanya kesesuaian sasaran anggaran yang relevan, maka akan memperlancar proses kerja serta meningkatkan prestasi aparatur pemerintah daerah dalam memformulasikan susunan anggaran untuk mencapai target-target anggaran yang telah ditetapkan. Selanjutnya untuk komitmen organisasi juga merupakan salah satu bagian yang memiliki relevansi dalam peningkatan kinerja aparat pemerintah sehingga perlu adanya perhatian khusus bagi pemerintah daerah dalam memperhatikan manifestasi dari komitmen setiap aparaturnya.

\section{DAFTAR PUSTAKA}

Amanta, K. B., Putra, I. M. P. A. and Werastuti, D. N. S. (2015) 'Pengaruh Komitmen Organisasi, Gaya Kepemimpinan, Ketepatan Skedul Penyusunan, Kejelasan Sasaran Anggaran, Partisipasi Penyusunan Anggaran dan Akuntabilitas Publik Terhadap Kinerja Manajerial( Studi Empiris Pada Kantor Dinas Se-Kabupaten Karangasem )', e-Journal S1 Ak Universitas Pendidikan Ganesha, 1(5).

Anwar (2018) 'Efek Moderasi Dari Komitmen Organisasi Terhadap Hubungan Antara Pengendalian Intern dan Kejelasan Sasaran Anggaran Terhadap Kinerja Manajerial (Survei Pada Pemerintah Daerah Kabupaten Maros)', 1(2012), pp. 46-50.

Harahap, M. and Abdullah (2016) 'Pengaruh tingkat pendidikan, pengalaman kerja, gaji dan komitmen organisasi terhadap kinerja pengelola keuangan pemerintah daerah kabupaten lebong', Journal of Economic Management dan Business, 17(April). 
Hidayat, T. (2016) 'Pengaruh Kejelasan Sasaran Anggaran, Struktur Desentralisasi Dan Locus of Control Terhadap Kinerja Manajerial', Akuntabilitas, 8(2), pp. 148-161. doi: 10.15408/akt.v8i2.2769.

Jalaluddin and Dafi, B. (2009) '( Studi Empiris pada Satuan Kerja Pemerintah Daerah ( SKPD ) Kota Banda Aceh ) Jalaluddin Fakultas Ekonomi Universitas Syiah Kuala Dafi Bahri Fakultas Ekonomi Universitas Syiah Kuala JURNAL TELAAH \& RISET AKUNTANSI 2 . TELAAH LITERATUR DAN PENGEMBANGAN HI', Jurnal Telaah dan Riset Akuntansi, 2(1), pp. 44-53.

Manurung, N. N. K. P., Dali, N. and Nurdin, E. (2019) 'Jurnal Progres Ekonomi Pembangunan ( JPEP ) Page : 87-98 Jurnal Progres Ekonomi Pembangunan ( JPEP ) Volume 4 , Nomor 1 ( 3 ), Tahun 2019 Page : 87-98', Jurnal Progres Ekonomi Pembangunan (JPEP, 4(3), pp. 87-98.

Mulyadi, A., Syamsidar and Dedy, E. (2018) 'Pengaruh Sistem Pelaporan dan Kejelasan Sasaran Anggaran Terhadap Akuntanbilitas Kinerja Instansi Pemerintah ( Studi Pada Satuan Kerja Pemerintah Aceh )', 2(2), pp. 95-101.

Nengsy, H. (2017) 'Pengaruh Kejelasan Sasaran Anggaran dan Akuntabilitas Terhadap Kinerja Manajerial PT. Perkebunan Nusantara V Pekanbaru', 6, pp. 1-16.

Nugroho, P. S. and Sumiyanti, T. (2017) 'Pengaruh Partisipasi Anggaran, Kejelasan Sasaran Anggaran Terhadap Kinerja Manajerial Dengan Komitmen Organisasi dan Politik Organisasi Sebagai Variabel Moderasi’, 8(November), pp. 104-118.

Nurhalimah, Darwanis and Syukriy Abdullah (2013) 'Pengaruh partisipasi penyusunan anggaran dan kejelasan sasaran anggaran terhadap kinerja aparatur perangkat daerah di pemerintah aceh', Jurnal Akuntansi Pascasarjana Universitas Syiah Kuala, 2(1), pp. 27-36.

Republik Indonesia. Peraturan Pemerintah Nomor 105 Tahun 2000 tentang Pengelolaan dan Pertanggungjawaban Keuangan Daerah.

Republik Indonesia. Undang-Undang Nomor 32 Tahun 2004 tentang Pemerintahan Daerah.

Republik Indonesia, Peraturan Pemerintah Nomor 58 Tahun 2005 tentang Pengelolaan Keuangan Daerah. Lembaga Negara Republik Indonesia Tahun 2005 Nomor 40.

Robbins, Stephen P dan Timothy A. Judge. 2013. Organizational Behavior. Edition 15. New Jersey: Pearson Education.

Sahir, S. H. et al. (2020). Keterampilan Manajerial Efektif. Cetakan 1. Medan: Yayasan Kita Menulis.

Silalahi, M. et al. (2020). Manajemen Pemerintahan. Gorontalo: Ideas Publishing. 
Silitonga, H. P., Widia, A., Irfan. (2018). Pengaruh Partisipasi Anggaran dan Akuntansi Pertanggungjawaban Terhadap Kinerja Manajerial Dengan Pengendalian Diri (Locus of Control) Sebagai Variabel Moderasi (Studi Kasus Pada Organisasi Perangkat Daerah (OPD) Kota Pematangsiantar. Prosiding Konferensi Nasional APPPTMA Ke 8. http://www.appptma.org/wp-content/uploads/2019/08/4.978623-90018-1-0.pdf.

Siwi, N. D. P., Kustomo, A. S. and Puspitasari, N. (2018) 'Pengaruh partisipasi anggaran dengan komitmen, budaya organisasi dan motivasi terhadap kinerja aparatur pemerintah kabupaten bondowoso', Bisma (Jurnal Bisnis dan Manajemen), 12(1), pp. 119-130.

Suleman, A. R. et al. (2020). BUMDES: Menuju Optimalisasi Ekonomi Desa. Medan: Yayasan Kita Menulis.

Suryana, G. A., Edy, S. and Putu Julianto (2017) '( Studi Kasus Pada Badan Penanggulangan Bencana Daerah Kabupaten Buleleng)', e-Journal S1 Ak Universitas Pendidikan Ganesha, 1(3).

Permendagri Nomor 59 Tahun 2007 tentang Perubahan atas Permendagri Nomor 13 Tahun 2006 tentang Pedoman Pengelolaan Keuangan Pemerintah Daerah.

Qotrunnada, S. S., Wiratno, A. and Supeno, S. (2018) 'Pengaruh Partisipasi Anggaran, Kejelasan Sasaran Anggaran, dan Komitmen Organisasi Terhadap Kinerja Manajerial (Studi Empiris Pada PD BPR BKK Purwokerto)', Jurnal Soedirman Accounting Review, 3(1), pp. 73-85. 